\author{
®А. Д. Бойченко \\ Харківський національний медичний університет
}

\title{
СИСТОЛІЧНА ТА ДІАСТОЛІЧНА ФУНКЦІЇ МІОКАРДА У НОВОНАРОДЖЕНИХ У РАННІЙ НЕОНАТАЛЬНИЙ ПЕРІОД
}

СИСТОЛІЧНА ТА ДІАСТОЛІЧНА ФУНКЦІЇ МІОКАРДА У НОВОНАРОДЖЕНИХ У РАННІЙ НЕОНАТАЛЬНИЙ ПЕРІОД. У РОНННЙ неонатальний період гіперкінетичний варіант гемодинаміки виявлено у 26 \% новонароджених, еукінетичний - у $60 \%(p<0,05)$ обстежених та гіпокінетичний - у 14 \% немовлят. Наявність функціонуючої відкритої артеріальної протоки (ії діаметр) та тривалість функціонування мають відбиток на типі центральної гемодинаміки. Параметри діастолічного потоку в новонароджених у ранній неонатальний період мають фазовий перерозподіл: для лівого шлуночка - з переважанням раннього діастолічного наповнення і помірним зростанням відношення раннього та пізнього трансмітрального потоків; для правого шлуночка - 3 превалюванням передсердного компонента.

СИСТОЛИЧЕСКАЯ И ДИАСТОЛИЧЕСКАЯ ФУНКЦИИ МИОКАРДА У НОВОРОЖДЕННЫХ В РАННЕМ НЕОНАТАЛЬНОМ ПЕРИОДЕ. В раннем неонатальном периоде гиперкинетический вариант гемодинамики выявлен у $26 \%$ новорожденных, эукинетический - у 60 \% (р<0,05) обследованных и гипокинетический - у 14 \% младенцев. Наличие функционирующего открытого артериального протока (его диаметр) и продолжительность функционирования имеют отпечаток на типе центральной гемодинамики. Параметры диастолического потока у новорожденных в раннем неонатальном периоде имеют фазовое перераспределение: для левого желудочка - с преобладанием раннего диастолического наполнения и умеренным ростом отношения раннего и позднего трансмитрального потоков; для правого желудочка - с превалированием предсердного компонента.

MYOCARDIAL SYSTOLIC AND DIASTOLIC FUNCTION OF NEWBORNS IN THE EARLY NEONATAL PERIOD. In the early neonatal period hyperkinetic variant of hemodynamics was found in $26 \%$ of newborns, eukinetic $-60 \%(p<0.05)$ of the examined patients, and hypokinetic - $14 \%$ of babies. The presence of a functioning open arterial duct - the diameter and duration of functioning influence the type of central hemodynamics. Parameters of newborn' diastolic flow in the early neonatal period have phase distribution: for the left ventricle - with the prevalence of the early diastolic filling and gradual increase in the ratio of the early and late transmitral flows; for the right ventricle - with the prevalence of the atrial component.

Ключові слова: новонароджені, систолічна та діастолічна функції, ранній неонатальний період.

Ключевые слова: новорожденные, систолическая и диастолическая функции, ранний неонатальный период.

Key words: newborns, systolic, diastolic function, early neonatal period.

Вступ. Незважаючи на досягнуті успіхи в неонатальній кардіології, проблема діагностики та лікування серцево-судинної патології у новонароджених залишається актуальною. Кожному неонатологу необхідне знання вікових та морфофункціональних особливостей серцево-судинної системи дітей з метою правильної оцінки функціональних показників, доклінічного розпізнавання захворювань серця і судин з подальшим обґрунтуванням раціональної терапії.

У дитячій кардіології ультразвукові методи дослідження залишаються найбільш пріоритетними $[1,2]$. В повсякденній практиці доплерехокардіографія (ДЕХОКГ) дає можливість визначити стан центральної гемодинаміки, виявити структурні відхилення та діагностувати міокардіальну дисфункцію. Міокардіальна дисфункція - патологічний процес порушення функції міокарда (правих чи лівих відділів серця, систолічної та/або діастолічної функцій), який може розвинутися при різній патології (кардіальній та/або соматичній, коронарогенного чи некоронарогенного генезу), викликаній різноманітними факторами.

Особливості раннього неонатального «перехідного» періоду накладають характерний відбиток на ехокардіографічні параметри. Розуміння даного питан- ня сприяє вирішенню ряду фундаментальних проблем післяпологової перебудови гемодинаміки. У перспективі новонароджений повинен успішно перейти до позаутробного існування без різких змін у кардіореспіраторній системі, включаючи зміни в обсязі легенів і зміни переднавантаження та постнавантаження на ліві й праві відділи серця, що має відбиток на функціональному стані міокарда [3]. Відповідно до рекомендацій American Society of Echocardiography (ASE) in collaboration with the European Association of Echocardiography (EAE) and the Association for European Pediatric Cardiologists (AEPC), цільова неонатальна ехокардіографія повинна проводитись як доповнення до клінічної оцінки стану гемодинаміки у новонароджених [4]. Етапи становлення центральної гемодинаміки, ії значення в клінічній практиці з метою прийняття рішень у конкретних ситуаціях залишаються недостатньо вивченими на сьогодні [1].

У постнатальний період при патологічних станах, як-то асфіксія, синдром дихальних розладів, гемолітична хвороба новонароджених, сепсис та ін., можуть розвиватися функціональні розлади зі сторони серцево-судинної системи. Функціональні розлади ускладнюють та пролонгують період постнатальної 


\section{Педіатрія}

адаптації; можуть призвести до недостатності трикуспідального та мітрального клапанів, тривалого функціонування відкритого овального отвору та пізнього закриття артеріальної протоки; поряд з метаболічними розладами сприяти розвитку порушень ритму серця; виникає необхідність проведення диференційної діагностики з уродженою структурною патологією та органічними ураженнями міокарда.

Розробка ефективних методів діагностики і терапії міокардіальної дисфункції у новонароджених $€$ вкрай значущою та актуальною. Актуальність вивчення проблеми функціональних розладів зумовлена вимогою проведення профілактичних заходів з метою попередження ризику прогресування кардіоваскулярних ускладнень у майбутньому.

Мета дослідження - вдосконалення ранньої діагностики серцево-судинних розладів у новонароджених у ранній неонатальний період шляхом аналізу показників центральної гемодинаміки, трансмітрального і транстрикуспідального потоків.

МАТЕРІАЛИ ТА МЕТОДИ. Обстежено 150 «умовно здорових» новонароджених у ранній неонатальний період (хлопчики - 55,3 \%, дівчатка - 44,7 \%), гестаційний вік - 38-40 тижнів, середня маса тіла при народженні - 3333,4 405,2 г, довжина тіла -

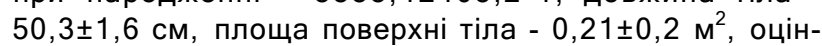
ка за шкалою Апгар - 8-9 балів. Внутрішньоутробний розвиток і ранній неонатальний період проходили без соматичних і неврологічних ускладнень; у задовільному стані всі були виписані додому на 3-5 доби життя.

Ехокардіографічне обстеження виконувалось на апараті «MyLab 25Gold» фірми «Esaote» (Італія). Доплерехокардіографія та розрахунок показників центральної гемодинаміки, визначення трансмітрального та транстрикуспідальних потоків проводилися за стандартними методиками відповідно до рекомендацій American Society of Echocardiography та запропонованими у посібниках з ехокардіографії [5-7]. При вивченні параметрів діастолічної функції обчислення виконували мінімум за трьома-чотирма комплексами при нормальному синусовому ритмі, тривалість інтервалів R-R коливалася не більше ніж на 5 \%. Умова проведення ДЕХОКГ - фізіологічний сон дитини для отримання достовірніших результатів та реєстрації істинної частоти серцевих скорочень новонароджених.

Статистичний аналіз проводився з використанням непараметричного критерію Manna-Whitney. Статистично значущою розбіжність вважали при $p<0,05$.

РЕЗУЛЬТАТИ ДОСЛІДЖЕННЯ ТАЇХ ОБГОВОРЕННЯ. При проведенні ДЕХОКГ на першу добу життя встановлено співвідношення між лівим (ЛШ) і правим шлуночками (ПШ) серця 1,2:1 з помірним пре-

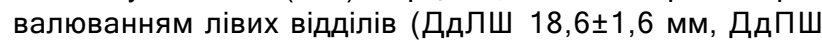
$15,5 \pm 2,4$ мм, p>0,05). 3 другої доби діастолічний розмір ПШ зменшується на 7,4 \% (p>0,05) щодо діаметра, визначеного на першу добу після народження, і на третю добу становить $12,7 \pm 1,8$ мм. На 4-5 добу життя ЛШ помірно зменшується (на 3,2 \%) щодо показника першої доби; збільшується співвідношення ЛШ:ПШ/ 1,35:1, що відбиває поступове зменшення судинно- го опору в малому колі кровообігу після народження та зниження середнього тиску в легеневій артерії (ЛА).

У перші дві доби розміри легеневої артерії превалюють над діаметром аорти (Ао). На першу добу

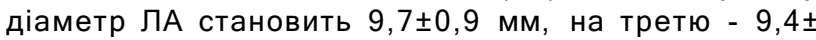

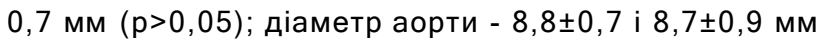
відповідно. Тільки наприкінці п'ятої доби розміри

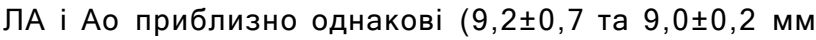
відповідно). Аналогічно змінюються розміри передсердь. У перші 24 год життя розмір правого перед-

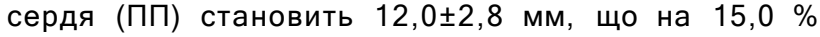
$(p>0,05)$ більше лівого передсердя. На третю добу розмір ПП складає $11,2 \pm 2,3$ мм, а на п'ятий день становить $10,9 \pm 1,5$ мм. Достовірне зменшення лівого передсердя (ЛП) визначається вже на п'яту добу

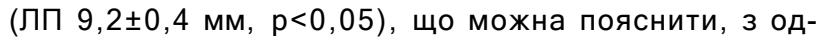
ного боку, закінченням функціонування відкритої артеріальної протоки, а з іншого - поступовим зменшенням тиску в легеневій артерії на п'яту добу (середній тиск у ЛА на першу добу - 43,7士

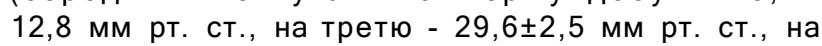
п'яту - 25,8 $\pm 8,1$ мм рт. ст).

Встановлена кореляційна залежність між лінійними розмірами лівого передсердя та правого шлуночка $(r=+0,77)$, що опосередковано свідчить про вплив фетальних комунікацій на морфологічні особливості міокарда. Наявність відкритої артеріальної протоки (iї діаметр) та тривалість функціонування впливають на формування режиму центральної гемодинаміки, про що свідчить зв'язок із систолічним індексом ( $r=-0,45, p<0,05$ та $r=-0,48, p<0,05$ відповідно).

Після народження протягом раннього неонатального періоду показники фракції викиду і фракційного скорочення волокон міокарда здорової новонародженої дитини мають високі значення: фракція викиду ЛШ становить $69,8 \pm 6,2$ \%, а показник фракційного скорочення волокон міокарда дорівнює

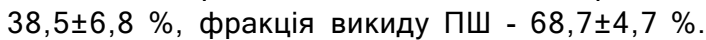

При аналізі показників центральної гемодинаміки встановлено три типи: гіперкінетичний варіант гемодинаміки виявлено у $26 \%$ новонароджених дітей, еукінетичний - у $60 \%(p<0,05)$ обстежених та гіпокінетичний - у $14 \%$ немовлят.

При дослідженні діастолічної функції шлуночків після народження у ранній неонатальний період відбувається перерозподіл фазового наповнення шлуночків серця - збільшення швидкості трансмітрального кровотоку з переважанням над транстрикуспідальним. Перерозподіляється фазове наповнення лівого шлуночка з переважанням кровотоку раннього наповнення над систолою передсердь $(E / A>1)$, тоді як для правого шлуночка характерним $\epsilon$ превалювання передсердного компонента $(E / A<1)$. Під час становлення гемодинаміки у чверті дітей відбувається повернення до попередньої стадії функціонування, причинами якого $є$ висока фізична активність і тахікардія. Нестійкість діастолічного наповнення шлуночків можна пояснити змінами перед- i післянавантаження на тлі часткового функціонування фетальних комунікацій (відкритий овальний отвір, функціонуюча артеріальна протока), а також збере- 


\section{Педіатрія}

ження неонатальної транзиторної легеневої гіпертензії та поступового зменшення тиску в легеневій артерії.

При вивченні показників діастолічного наповнювання шлуночків серця у ранній неонатальний період було встановлено опорні показники, які можна вважати нормативними: для ЛШ - E/A 1,0-1,5 ум. од., ДТе - 60-90 мс, IVRT - 50-60 мс, час діастоли - 300350 мс; для ПШ - Е/А 0,6-1,1 ум. од., ДТе - 51-90 мс, IVRT - 45-55 мс, час діастоли - 290-340 мс.

Таким чином, необхідність проведення ДЕХОКГдослідження у новонароджених у ранній неонатальний період зумовлена стадійністю становлення систолічної та діастолічної функцій, необхідністю орієнтації меж норми та патології під час перехідного постнатального становлення гемодинаміки.

ВИСНовКИ. 1. У ранній неонатальний період гіперкінетичний варіант гемодинаміки виявлено у $26 \%$ новонароджених, еукінетичний - у $60 \%(p<0,05)$ обстежених та гіпокінетичний - у $14 \%$ немовлят.
2. Наявність функціонуючої відкритої артеріальної протоки (ії діаметр) та тривалість функціонування мають відбиток на типі центральної гемодинаміки.

3. Становлення діастолічної функції міокарда у новонароджених відбувається протягом першого тижня життя. Параметри діастолічного потоку в новонароджених у ранній неонатальний період мають фазовий перерозподіл: для лівого шлуночка - 3 превалюванням раннього діастолічного наповнення і помірним зростанням відношення раннього та пізнього трансмітрального потоків; для правого шлуночка - 3 превалюванням передсердного компонента.

4. Ехокардіографічне обстеження $€$ зручним неінвазивним методом діагностики міокардіальної дисфункції в ранній неонатальний період.

ПЕРСПЕКТИВИ ПОДАЛЬШИХ ДОСЛІДЖЕНЬ. ДОслідити та вивчити функціональні розлади зі сторони серцево-судинної системи у новонароджених, які народжені від матерів з екстрагенітальною патологією, з визначенням кардіоваскулярних ризиків.

\section{СПИСОК ЛІТЕРАТУРИ}

1. Koert A. de Waal. The Methodology of DopplerDerived Central Blood Flow Measurements in Newborn Infants. /Koert A. de Waal // International Journal of Pediatrics. - Vol. 2012, Article ID 680162, 13 pages. http://dx.doi.org/10.1 155/2012/680162.

2. Massimiliano Cantinotti. Nomograms for Blood Flow and Tissue Doppler Velocities to Evaluate Diastolic Function in Children: A Critical Review / Massimiliano Cantinotti, Leo Lopez // Journal of the American Society of Echocardiography - 2013. Vol. 26. - P. 126-141.

3. Myocardial function in premature infants: a longitudinal observational study / Beate Horsberg Eriksen, Eirik Nestaas, Torstein Hole [et al.] // BMJ Open. 2013;3:e002441 doi:10.1136/bmjopen-2012-002441.

4. Targeted Neonatal Echocardiography in the Neonatal Intensive Care Unit: Practice Guidelines and
Recommendat ions for Training / Luc Mertens, Istvan Seri, Jan Marek [et al.] // Eur. J. Echocardiogr. - 2011. Vol. 12 (10). - P. 715-736.

5. Guidelines and Standards for Performance of a Pediatric Echocardiogram: A Report from the Task Force of the Pediatric Council of the American Society of Echocardiography / Wyman W. Lai, Tal Geva, Girish S. Shirali [et al] // Journal of the American Society of Echocardiography. - 2007. - Vol. 19 (12). - P. 14131429.

6. Рыбакова М. К. Практическое руководство по ультразвуковой диагностике / М. К. Рыбакова, М. Н. Алехин, В. В. Митьков // Эхокардиография. М. : Издательский дом Видар-М, 2008. - 512 с.

7. Прахов А. В. О проекте рабочей классификации функциональных кардиопатий детей периода новорожденности. - 2007. - 5 с. 